\title{
Development of sulla (Hedysarum coronarium) for better adaptation to grazing
}

\author{
G.B. DOUGLAS, R.G. KEOGH and A.G. FOOTE
}

AgResearch Grasslands, Private Bag 11008, Palmerston North

\section{Abstract}

Sulla is potentially useful in New Zealand as a forage for grazing, hay and silage, in addition to its established use for soil conservation. The plant produces up to $25 \mathrm{t} \mathrm{DM} / \mathrm{ha} /$ year and is a highly nutritious feed; it contains condensed tannins (CT) which prevent bloat and improve protein utilisation; and high livestock utilisation of leaf and stem is possible. Established stands of sulla can be maintained for several years under good management, but there have been many reports of poor persistence. In an effort to improve stand persistence, particularly under grazing, two evaluations were conducted near Palmerston North in 1995-97. Trial 1 screened 32 lines of sulla, including commercial cultivars, for a range of morphological attributes (e.g., habit, height, spread, vigour, herbage mass), whereas Trial 2 assessed similar attributes for 134 plants of cv. Grasslands Aokau, involved in an earlier grazing trial. Foliar levels of extractable CT were also determined in Trial 1, which is the first documentation of CT variation in the species. In both trials, plants survived for up to 2.5 years and seed was collected from 145 (Trial 1) and 31 (Trial 2) selected plants in early 1997 . The plants selected typically had prostrate growth habit, moderate to high plant diameter and branch number, and high plant vigour. CT levels, assayed by a vanillin/ $\mathrm{HCl}$ procedure, averaged $1.2-3.5 \% \mathrm{DM}$ in most lines and were $36-81 \%$ higher for six samples assayed by a butanol/HCl method. Some CT levels may be sufficiently high to have a slight nutritional disadvantage to ruminants, but this could potentially be overcome by growing sulla with nonCT containing forages. Progeny from selected plants in each trial are being evaluated under more frequent grazing, and their seed will be harvested in autumn 1999.

Keywords: condensed tannins, cultivars, Hedysarum coronarium, legume, persistence, sulla

\section{Introduction}

Sulla (Hedysarum coronarium L.) is a winter-active, short-lived perennial legume, usually biennial, which originates from the north temperate regions of the world. In the central and western Mediterranean regions, it is used widely for hay, silage and greenfeed (Kernick 1978; Martinello \& Ciola 1994). The species was introduced into New Zealand as a potentially useful species for revegetating erosion-prone sites because of attributes such as a well-developed tap-root system, nitrogen fixing capability, and dense ground cover (Douglas 1984). Sulla is cross pollinated, with honey bees thought to be the major pollinator (McGregor 1976).

Since the late 1980s, research in New Zealand has shown the potential of sulla as a forage for sheep (Foote 1988; Terrill et al. 1992a) and dairy cattle. The forage is of high quality (Douglas et al. 1999) and stands can produce up to $25 \mathrm{t}$ dry matter (DM)/ha/year (Krishna 1993). Sulla contains condensed tannins (CT) in its leaves and stems at concentrations of $5-10 \%$ DM (Stienezen et al. 1996). CT have advantages in preventing bloat and improving the efficiency of forage protein utilisation in ruminants. The type of CT in sulla also has potential value as a natural anthelmintic, as it reduces the establishment of ingested parasite larvae and also reduces the dagginess commonly associated with parasitism, thereby reducing the incidence of flystrike (Niezen et al. 1995). Preliminary results also indicate that sulla makes excellent silage (Niezen et al. 1998).

Although satisfactory stands of sulla have been established and maintained for several years, some farmers have observed poor persistence, and even complete disappearance of sulla. This might be because of factors such as low seed production every 1-2 years and hence negligible subsequent re-establishment, unsuitable grazing/cutting management, inadequate weed control, disease, lack of cold tolerance, and soil nutrient limitations. Poor persistence, particularly under grazing, may also result from the inherent characteristics of the two currently available New Zealand cultivars, Grasslands Aokau and Necton, which are mostly semierect and erect, respectively. Erectness in other species such as sainfoin and birdsfoot trefoil has been linked to poor persistence under grazing. In an effort to improve the persistence of sulla, a screening of local and imported lines was begun in 1995 (Trial 1), and plants of Grasslands Aokau selected from survivors from a recent grazing trial were also evaluated (Trial 2). This paper 
reports some of the morphological variation in the material, and outlines progress towards developing a more persistent selection. CT levels in the lines in Trial 1 are also reported.

\section{Materials and methods}

Both trials were conducted in the same field block at AgResearch's Aorangi lowland research station, $15 \mathrm{~km}$ from Palmerston North. The soil was a free-draining Kairanga silt loam $(\mathrm{pH}=5.5$, Olsen $\mathrm{P}=19 \mathrm{mg} / \mathrm{kg}$ soil, $\mathrm{S}\left(\mathrm{SO}_{4}\right)=13 \mathrm{mg} / \mathrm{kg}$ soil). In 1994/95 the block had a welldeveloped stand of sulla which was grazed rotationally with sheep (Douglas et al. 1999). At the conclusion of this trial, the stand was destroyed and the land cultivated, except for 0.2 ha of sulla which was retained. Trial 1 was established on the cultivated area whereas Trial 2 involved plants from the retained area.

Trial 1 (local and imported germplasm): Plants of 32 lines of sulla were grown in a glasshouse in mid 1995 and inoculated with an appropriate Rhizobium strain (Douglas \& Foote 1985). These comprised several cultivars including Grasslands Aokau (NZ), Necton (NZ), Grimaldi (Italy) and Sparacia (Italy), and unnamed material from New Zealand and overseas (Table 1). Plants aged 2-3 months were transplanted into the field in October 1995. They were arranged in 3 randomised complete blocks, and plots (experimental units) were single rows of up to 20 plants. Owing to plant shortages, not all lines were replicated 3 times. Between- and within-row plant spacings were $3 \mathrm{~m}$ and $2 \mathrm{~m}$, respectively. Weeds were controlled by mowing, grubbing and use of herbicides between the rows and around plants. Herbicides used were dicamba ( $300 \mathrm{~g} / \mathrm{ha})$ plus glyphosate $(1.08 \mathrm{~kg} / \mathrm{ha})$ and a shield cone was used to prevent drift onto plants. All sulla plants were cut to $100 \mathrm{~mm}$ height and $300 \mathrm{~mm}$ diameter in mid February 1996. Seedling sulla plants were controlled with bromoxynil ( $800 \mathrm{~g} / \mathrm{ha})$.

Plants were assessed from December 1995 until November 1997 for a range of attributes including survival (\%), growth habit (prostrate, semi-erect, erect), growth stage (vegetative, flowering), rhizome development (presence, absence), height $(\mathrm{mm})$, diameter $(\mathrm{mm})$, vigour (score of 1 (low) to 5), herbage mass and regrowth (score of 1 (low) to 5). In February (152 samples) and December (146 samples) 1996, the edible foliage (lamina + stem < $3 \mathrm{~mm}$ diameter) from one or two plants per plot was sampled, freeze-dried, ground to pass through a $1 \mathrm{~mm}$ aperture sieve, and assayed for extractable CT content. Samples of $25 \mathrm{mg}$ were extracted with $70 \%$ aqueous acetone for 1 hour, and $0.25 \mathrm{ml}$ subsamples were used in the vanillin/HCl assay (Broadhurst \& Jones 1978), with purified extracts of sulla CT used as standards. Six samples, covering the range of CT estimates found for the February 1996 samples, were re-analysed and compared with results from using the butanol/ $\mathrm{HCl}$ (Terrill et al. 1992b) colorimetric procedure, also following extraction with $70 \%$ aqueous acetone.

In mid-December 1996, unwanted plants were cut to remove flowers, and seed was collected from selected plants in January/February 1997, for progeny testing. Seed was also collected as a bulk from all remaining plants in January, 1998.

Trial 2 (previously grazed Grasslands Aokau): Plants remaining in the 0.2 ha of sulla were trimmed to $50 \mathrm{~mm}$ height in June 1995. In September/October 1995, 134 plants were selected which had relatively high regrowth, healthy foliage, and were at least $2 \mathrm{~m}$ apart. Plants were assessed for several attributes in mid-December 1995 including growth habit, height, diameter, and vigour.

All plants were trimmed to $100 \mathrm{~mm}$ height and 150 mm diameter on 21 December 1995, and assessed for regrowth mass and vigour in February and March 1996. Live plants in October 1996 were assessed for height, spread, mass, vigour, growth habit, and presence of flowers. On the basis of data collected in 1995 and 1996, 31 plants were selected in November 1996 for interpollination and seed collection in February 1997. Unselected plants were de-flowered. Assessments of remaining live plants were conducted in April and October/November 1997, mainly to determine longevity of the selected plants. Throughout the evaluation, weeds including unselected sulla plants and seedlings, were controlled using the same methods as used in Trial 1.

\section{Results}

\section{Trial 1}

Morphological attributes: There were significant differences between lines for several attributes including flower number and plant vigour in the first season, mass of regrowth following cutting in February 1996, and herbage mass in October 1996 (Table 1). Despite variation in plant vigour, no line displayed severe chlorosis or necrosis or other symptoms, which would justify its rejection on the basis of vigour alone.

Over all lines, survival from planting averaged 69\% after one year and $15 \%$ after two years. There was variation in survival between lines ranging from 40 $100 \%$ after one year and $0-53 \%$ after two years. The predominant growth habit of all lines in January 1996 was prostrate, except for AL1542 from Switzerland, which was mostly erect. Nine months later, there were approximately equal numbers of mainly prostrate and semi-erect lines. In October 1996, plants of most lines 


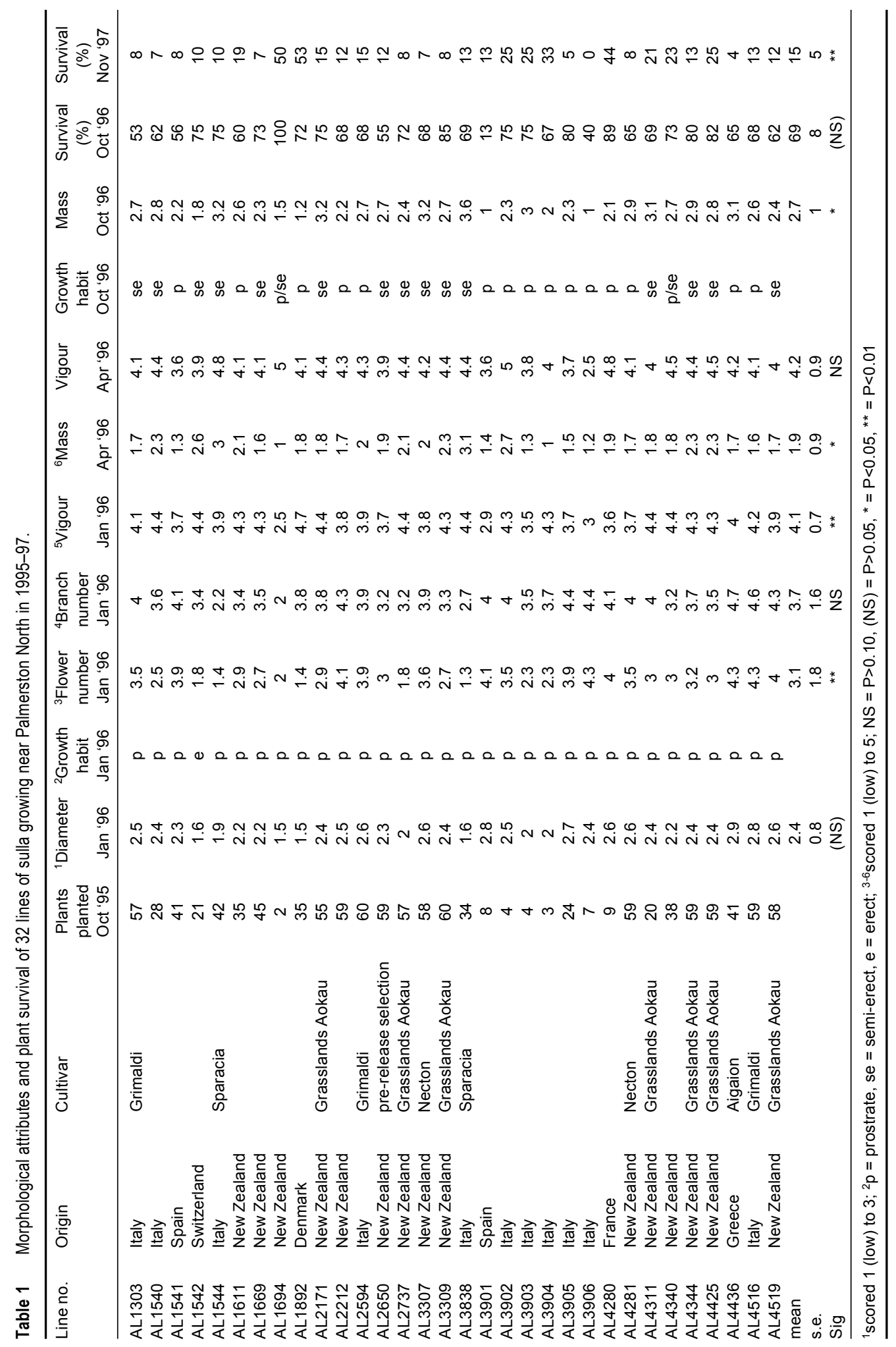


were $300-500 \mathrm{~mm}$ high and $1-1.5 \mathrm{~m}$ diameter. AL3838 was the only line which had some plants (6 of 31) with diameters exceeding $2 \mathrm{~m}$, and it had the highest average herbage mass in spring 1996 of 400-450 g/plant. There was large variation within lines; for example the 31 plants of AL3838 in October 1996 had 1, 7, 14 and 9 plants with vigour scores of 2, 3, 4 and 5, respectively; 7 plants were prostrate and 24 semi-erect; 1 plant was vegetative, 3 were at flower bud and 27 at full flower stage; and 6 plants had small, 18 medium and 7 large leaves.

The most uniform line in the evaluation was AL1892 from Denmark. It was prostrate at all assessments, had moderate to high vigour, solely vegetative growth in spring, and low spring herbage yield, for example, less than $70 \mathrm{~g} \mathrm{DM} /$ plant in October 1996. It also had relatively long-lived plants with survival being over $50 \%$ after 27 months (Table 1).

Condensed tannins: Foliar CT levels in most lines at the two samplings averaged $1.2-3.5 \%$ DM (Table 2). Notable exceptions were the negligible CT level in AL3906 in February and the content of $6.6 \%$ DM in AL4280 in December, which was the highest value recorded. Within four lines (AL1303, 3902, 3905, 4281), levels in December were 2- to 3-fold higher $(\mathrm{P}<0.05)$ than in February, and a similar but non-significant trend occurred for most other lines.

The three lines of the cultivar Grimaldi (AL1303, 2594, 4516) had $\mathrm{CT}$ levels ranging $(\mathrm{P}<0.05)$ from 1.4 to $3.2 \%$ DM in February, but averaging 3.0-3.3\% DM in December. In contrast, CT contents of the seven lines of Grasslands Aokau were approximately constant within and between samplings, averaging 2.3\% DM.

The six samples analysed using vanillin/ $\mathrm{HCl}$ and butanol/HCl colorometric procedures had respective $\mathrm{CT}$ concentrations (\% of DM) of 2.72/4.12 (AL4519 and 2594), 3.56/4.85 (AL4516), 2.12/3.84 (AL1303), 3.39/ 5.46 (AL2171), and 4.63/6.70 (AL1892). The butanol/ $\mathrm{HCl}$ procedure estimated extractable CT contents 36$81 \%$ higher (average $=54 \%$ ) than those from vanillin/ $\mathrm{HCl}$.

\section{Trial 2}

Over $50 \%$ of the plants at all assessments were semierect, most of the remainder being prostrate. The seven live plants remaining in October 1997 were all semierect. All plants survived cutting in December 1995 and had moderately vigorous foliage $2-3$ months later. Approximately one-third of plants had moderate regrowth mass and between-plant variability was particularly apparent for this attribute since the two most frequent scores ( 2 and 3 ) classified only half the plant population.
Table 2 Foliar content of condensed tannins (\%DM) in 32 lines of sulla growing near Palmerston North in February and December 1996.

\begin{tabular}{|c|c|c|c|c|c|c|c|}
\hline \multirow[b]{2}{*}{ Line no. } & \multicolumn{3}{|c|}{--February 1996-- } & \multicolumn{3}{|c|}{--December 1996-- } & \multirow[b]{2}{*}{$\mathrm{Sig}^{2}$} \\
\hline & $\mathrm{n}^{1}$ & mean & s.e. & $\mathrm{n}$ & mean & s.e. & \\
\hline AL1303 & 6 & 1.35 & 0.31 & 6 & 3.05 & 0.51 & * \\
\hline AL1540 & 5 & 1.58 & 0.32 & 5 & 2.37 & 0.71 & NS \\
\hline AL1541 & 6 & 2.12 & 0.32 & 6 & 2.3 & 0.28 & NS \\
\hline AL1542 & 3 & 2.15 & 0.96 & 4 & 4.31 & 1.06 & NS \\
\hline AL1544 & 6 & 2.91 & 0.45 & 5 & 3.39 & 0.25 & NS \\
\hline AL1611 & 4 & 2.08 & 0.62 & 4 & 3.19 & 0.59 & NS \\
\hline AL1669 & 6 & 2.48 & 0.65 & 6 & 2.9 & 0.82 & NS \\
\hline AL1694 & 1 & 4.1 & & 1 & 3.23 & & \\
\hline AL1892 & 6 & 4.44 & 0.27 & 5 & 3.75 & 0.62 & NS \\
\hline AL2171 & 6 & 2.02 & 0.47 & 6 & 2.48 & 0.55 & NS \\
\hline AL2212 & 6 & 1.24 & 0.36 & 6 & 2.41 & 0.34 & * \\
\hline AL2594 & 6 & 2.24 & 0.15 & 6 & 3.01 & 0.6 & NS \\
\hline AL2650 & 6 & 2.24 & 0.32 & 6 & 2.29 & 0.29 & NS \\
\hline AL2737 & 6 & 1.98 & 0.3 & 5 & 1.85 & 0.59 & NS \\
\hline AL3307 & 6 & 2.48 & 0.6 & 6 & 2.94 & 0.36 & NS \\
\hline AL3309 & 6 & 1.62 & 0.39 & 6 & 2.53 & 0.33 & NS \\
\hline AL3838 & 6 & 2.58 & 0.31 & 6 & 3.31 & 0.25 & NS \\
\hline AL3901 & 2 & 1.49 & 0.52 & 0 & & & \\
\hline AL3902 & 2 & 1.7 & 0.45 & 2 & 5.68 & 0.69 & * \\
\hline AL3903 & 2 & 4.3 & 0.07 & 2 & 5.0 & 0.45 & NS \\
\hline AL3904 & 2 & 3.4 & 0.21 & 2 & 5.13 & 0.55 & NS \\
\hline AL3905 & 4 & 1.59 & 0.25 & 3 & 3.74 & 0.33 & ** \\
\hline AL3906 & 2 & 0.28 & 0.07 & 1 & 4.98 & & \\
\hline AL4280 & 2 & 2.5 & 0.14 & 2 & 6.59 & 1.37 & NS \\
\hline AL4281 & 6 & 1.88 & 0.31 & 6 & 2.99 & 0.38 & * \\
\hline AL4311 & 5 & 1.54 & 0.44 & 5 & 2.26 & 0.35 & NS \\
\hline AL4340 & 4 & 1.62 & 0.44 & 4 & 1.94 & 0.41 & NS \\
\hline AL4344 & 6 & 2.59 & 0.61 & 6 & 2.65 & 0.52 & NS \\
\hline AL4425 & 6 & 2.18 & 0.69 & 6 & 3.01 & 0.89 & NS \\
\hline AL4436 & 6 & 2.42 & 0.33 & 6 & 2.78 & 0.52 & NS \\
\hline AL4516 & 6 & 3.24 & 0.35 & 6 & 3.33 & 0.91 & NS \\
\hline AL4519 & 6 & 2.48 & 0.31 & 6 & 2.82 & 0.63 & NS \\
\hline
\end{tabular}

${ }^{1}$ number of plants sampled; ${ }^{2}$ significance of difference between means (NS $=\mathrm{P}>0.05,{ }^{*}=\mathrm{P}<0.05,{ }^{* *}=\mathrm{P}<0.01$ )

Considerable variation occurred in plant height and diameter. In December 1995, height and spread of the 134 plants averaged $400 \mathrm{~mm}$ (range 130-700 $\mathrm{mm}$ ) and $2290 \mathrm{~mm}$ (range $840-3300 \mathrm{~mm}$ ), respectively. In contrast, the 105 remaining plants in October 1996 had average height and spread of $240 \mathrm{~mm}$ (range 50-800 $\mathrm{mm}$ ) and $490 \mathrm{~mm}$ (range 100-1250 mm), respectively. In October 1997, height and spread of four of the seven surviving plants were less than $500 \mathrm{~mm}$, whereas other plants were larger.

\section{Discussion}

Sulla in Trial 1 exhibited considerable variation between lines for several morphological attributes and foliar concentration of CT. This is the first report of genotypic variation for $\mathrm{CT}$ in this species. Large morphological variation occurred within numerous lines such as AL2212, AL3838 (Sparacia), AL4425 (Grasslands Aokau) and AL4436 (Aigaion), and therefore individual 
plants were selected from within most lines throughout the trial. Selected plants typically had moderate to high diameter and branch number, prostrate growth habit, and high plant vigour. Progeny lines from these plants are being evaluated near Palmerston North under frequent grazing, as this is the targeted use for the new selection. A similar approach is being taken with the progeny from Trial 2, and it is envisaged that nucleus seed will be collected from both trials in autumn 1999. The final release will comprise seed from one or both progeny evaluations, depending on results.

Some of the cultivars developed in Mediterranean countries, such as Grimaldi (Bonciarelli \& Monotti 1976) from Italy and Sparacia from Sicily (Frame et al. 1998) and Italy, have erect growth habits in those countries, which makes them most amenable to cutting for greenfeed, hay and/or silage. However, in the Manawatu environment, the cultivars exhibited prostrate or semierect habits, which may enhance their suitability for in situ grazing. The cultivars may grow more upright in stands than as spaced plants, but the extent of this is unknown. Information is lacking on the relative tolerance to grazing of prostrate and erect types of sulla, particularly for crown development and source of growing points, and degree of burial of the crown. However, experience with other tap-rooted forage species such as birdsfoot trefoil (Seaney \& Henson 1970; Widdup et al. 1987), but not lucerne (Purves, pers. comm), suggests that cultivars with semi-erect/prostrate growth have increased persistence under grazing compared with erect types; hence the selection towards prostrateness in this study. The development of stolons/rhizomes could improve persistence of sulla but their occurrence has not been reported elsewhere and they were not detected in any plant in this study. Rhizomatous species occur within the genus Hedysarum, such as $H$. mongolicum from China (Li \& Hovin 1983), and the potential to use these as forages and as genetic resources for incorporating rhizome development into sulla cultivars should be appraised.

The predominant growth habit of surviving plants of several lines in Trial 1, and of plants in Trial 2, changed over 1-2 years from prostrate to semi-erect. This was a significant result as it indicated that semierect germplasm was relatively long-lived, and therefore that it should receive greatest attention in a programme aiming to develop a more persistent selection. The most convincing data to support this were from Trial 2 where $66 \%$ of 105 plants were semi-erect in October 1996, whereas in October 1997, all seven surviving plants were semi-erect. In contrast, the results for Trial 1 should be treated cautiously as comparisons were made between growth habits of plants in January and October. Hence factors such as physiological development and the timing of vertical and horizontal growth could be accounting for most of the differences in habit, rather than real increases in the proportion of semi-erect plants.

The 300-700 mm heights of spaced plants in both trials were less than those usually found in sulla swards. For example, established swards of Grasslands Aokau grown in several trials at research stations near Palmerston North since the late 1980s, have usually had canopy heights of 800-1200 mm. However, recently a sward of this cultivar grew $1.5-1.6 \mathrm{~m}$ tall. It is likely that the new selection developed in this programme will be morphologically different in swards compared with as spaced plants, and the extent of this will be determined as soon as possible and in comparison with at least the two existing New Zealand sulla cultivars. Swards could involve sulla alone, or in combination with appropriate companion species.

The results for survival found that individual sulla plants generally survived for less than 2 years, although a few plants in Trial 1 were still alive in January 1998, aged 29 months. The age of plants in Trial 2 was less certain since some plants may have developed in spring 1994. However, their development suggested that they were all seedlings in autumn 1995, and assuming this, the oldest plants were 29-31 months. Progeny from all relatively long-lived plants are included in the current evaluations. Line AL1892, in particular, had high survival, as well as several other advantages, and this could be a candidate for cultivar release as is, providing that its herbage yield is acceptable in swards.

Extractable foliar CT levels in the sulla lines sampled in December and February in this trial, and assayed using the vanillin $/ \mathrm{HCl}$ method, were similar to or exceeded that determined for a line sampled in late spring at Palmerston North (1.3\% DM; Terrill et al. 1992b). This line, previously unidentified, was Grasslands Aokau, and in the present study it had an average CT content of $2.3 \% \mathrm{DM}$, almost twice that estimated earlier, and contents of the seven samples of Grasslands Aokau were similar $(\mathrm{P}>0.05)$ amongst and within seasons. Sulla also has relatively constant $\mathrm{CT}$ content at different sites (Douglas et al. 1993). Possible reasons for the higher CT values found here compared with those of Terrill et al. (1992b) include slight differences in plant parts sampled and plant maturity.

The butanol/HCl procedure estimated CT levels 40$80 \%$ higher than those using vanillin $/ \mathrm{HCl}$, and an earlier estimate $(77 \%)$ was within this range (Terrill et al. 1992b). Sulla CT bound to protein and fibre can account for $20-40 \%$ of total CT (Terrill et al. 1992a, b; Douglas et al. 1993), but bound components were not estimated. If total $\mathrm{CT}$ had been estimated using the butanol $/ \mathrm{HCl}$ procedure, some estimates could have been in the range $5-10 \%$ DM. In sheep grazing pure swards of Lotus 
pedunculatus cv. Grasslands Maku, total CT levels exceeding 5\% DM can adversely affect ruminant animal nutrition, primarily through reducing voluntary herbage intake and decreasing rumen fibre digestion (Barry 1989). Some adverse effects of CT in sulla have been found when fed as a sole diet, for example reduced DM and nitrogen digestibility and lower carcass weight and carcass dressing-out percent (Stienezen et al. 1996; Douglas et al. 1999). However, the advantages of sulla such as high herbage yield and high animal liveweight gains, and the possibility of growing it in combination with non-CT forages, to dilute the effect of the CT, suggest that attempts to alter foliar CT content through breeding, are unwarranted.

In summary, most of the spaced-plant populations exhibited considerable morphological variation for a range of plant attributes. Relatively long-lived, prostrate/semierect plants have been selected with the aim of improving the persistence of sulla under grazing. Progeny from these plants is being evaluated under periodic grazing with sheep. The adjustment of condensed tannin content in sulla through plant breeding, is not a high priority.

\section{ACKNOWLEDGEMENTS}

This research was funded by the Foundation for Research, Science and Technology. D. Sagar assisted with land preparation and management.

\section{REFERENCES}

Barry, T.N. 1989. Condensed tannins; their role in ruminant protein and carbohydrate digestion and possible effects upon the rumen ecosystem. pp. 140. In: The role of protozoa and fungi in ruminant digestion. Nolan, J.V.; Long, R.A. (ed.) Armidale, Australia: University of New England Press.

Bonciarelli, F.; Monotti, M. 1976. "Grimaldi", a new cultivar of sulla (Hedysarum coronarium L.). Rivista di agronomia 10: 52-56.

Broadhurst, R.B.; Jones, W.T. 1978. Analysis of condensed tannins using acidified vanillin. Journal of the science of food and agriculture 29: 788-794.

Douglas, G.B. 1984. Seed production of sulla - a plant for soil conservation. Proceedings of the New Zealand Grassland Association 45: 239-242.

Douglas, G.B.; Donkers, P.; Foote, A.G.; Barry, T.N. 1993. Determination of extractable and bound condensed tannins in forage species. Proceedings of the XVII International Grassland Congress. 1: 204206.

Douglas, G.B.; Foote, A.G. 1985. Dry matter and seed yields of sulla (Hedysarum coronarium L.). New Zealand journal of experimental agriculture 13: 97-
99.

Douglas, G.B.; Stienezen, M.; Waghorn, G.C.; Foote, A.G.; Purchas, R.W. 1999. Effect of condensed tannins in birdsfoot trefoil (Lotus corniculatus) and sulla (Hedysarum coronarium) on body weight, carcass fat depth, and wool growth of lambs in New Zealand. New Zealand journal of agricultural research 42: 55-63.

Foote, A.G. 1988. Local cultivar adaptation for Mediterranean's sulla. New Zealand journal of agriculture Feb/Mar: 25-27.

Frame, J.; Charlton, J.F.L.; Laidlaw, A.S. 1998. Temperate forage legumes. Commonwealth Agricultural Bureau International: pp. 299-304.

Kernick, M.D. 1978. Technical data sheet No.25 Papilionaceae (= Fabaceae). Hedysarum spp. Kernick, M.D.: Ecological management of arid and semi arid rangelands in Africa and the Near and Middle East EMASAR Phase II 4: 597-619.

Krishna, H. 1993. Sulla (Hedysarum coronarium L): an agronomic evaluation. Unpublished $\mathrm{PhD}$ thesis, Massey University, Palmerston North. 251p.

Li, M.; Hovin, A.W. 1983. Hedysarum mongolicum Turcz: an important protein resource legume on dry sandy land. Proceedings of the XIV International Grassland Congress: 190-192.

Martiniello, P.; Ciola, A. 1994. The effect of agronomic factors on seed and forage production in perennial legumes sainfoin (Onobrychis viciifolia Scop.) and French honeysuckle (Hedysarum coronarium L.). Grass and forage science 49: 121-129.

McGregor, S.E. 1976. Insect pollination of cultivated crop plants. United States Department of Agriculture. Handbook No. 496.

Niezen, J.H.; Waghorn, G.C.; Lyons, T.B.; Corson, D.C. 1998. The ensiling capabilities of sulla compared to pasture. Proceedings of the New Zealand Grassland Association 60: 105-109.

Niezen, J.H.; Waghorn, T.S.; Waghorn, G.C.; Charleston, W.A.G. 1995. Lamb growth and faecal egg count when grazing lucerne (Medicago sativa) or sulla (Hedysarum coronarium). Journal of agricultural science, Cambridge 125: 281-289.

Seaney, R.R.; Henson, P.R. 1970. Birdsfoot trefoil. Advances in agronomy 22: 119-157.

Stienezen, M.; Waghorn, G.C.; Douglas, G.B. 1996. Digestibility and effects of condensed tannins on digestion of sulla (Hedysarum coronarium) when fed to sheep. New Zealand journal of agricultural research 39: 215-221.

Terrill, T.H.; Douglas, G.B.; Foote, A.G.; Purchas, R.W.; Wilson, G.F.; Barry, T.N. 1992a. Effect of condensed tannins upon body growth, wool growth and rumen metabolism in sheep grazing sulla (Hedysarum 
coronarium) and perennial pasture. Journal of agricultural science 119: 265-273.

Terrill, T.H.; Rowan, A.M.; Douglas, G.B.; Barry, T.N. 1992b. Determination of extractable and bound condensed tannin concentrations in forage plants, protein concentrate meals and cereal grains. Journal of the science of food and agriculture 58: 321-329.

Widdup, K.H.; Keoghan, J.M.; Ryan, D.L.; Chapman, H. 1987. Breeding Lotus corniculatus for South Island tussock country. Proceedings of the New Zealand Grassland Association 48: 119-124. 